\title{
Servant Leadership in Teaching
}

\author{
Iyer Ramajanaki Doraiswamy \\ (Corresponding Author) \\ Department of Management Studies, Shah and Anchor Kutchhi Engineering College \\ Mumbai, India \\ Tel: +919967181076 E-mail: $\underline{\text { ramaiyer2008@gmail.com }}$
}

\author{
Accepted: Jan 30, 2012 Published: Feb 28, 2013 \\ Doi:10.5296/ijhrs.v3i1.3035 URL: http://dx.doi.org/10.5296/ijhrs.v3i1.3035
}

\begin{abstract}
Sound education is the supporting spine for the economic and social development of any nation and is primarily responsible for eradication of poverty and enhancement of an individual's earnings. Teachers are the gatekeepers for the holistic character building of students and hence it is essential that they in turn are taken care of by effective leadership at schools. Leadership in schools should bring about a transformation encourages great and committed teaching. School leaders can pave way for setting clear directions and the fertile background for professional development of teachers.

Teaching, like nursing is a noble profession that brings to minds an image of vocation and dedication.Servant leadership is a unique approach to leadership that emphasizes on selfless service of followers by being their servant, rather than assuming a command and control hierarchical role in the organization. This paper tries to examine the concept of servant leadership in the context of teaching.
\end{abstract}

Key words: Servant Leadership, Teacher,Teaching

\section{The Lone Crusader: Teacher}

We cannot underestimate the importance of a teacher in the life of an individual. Teachers have duties that have vital effects over students like motivating them, planning for class activities, providing for additional knowledge and skills for students, getting the class under discipline and guiding and mentoring the students. Schools environments are mostly characterized by discipline and order issues, relationship problems among teachers, administrators and colleagues, over crowded classes, lack of necessary resources, insufficient infrastructure, changing and demanding policies and to top it all ambiguity in roles of teachers (Semra, 2000). Teaching can be an isolating and a lonely profession. Strange though it sounds, if we really look at the situation teachers are always surrounded by students and others but when they enter the classroom they are on their own. They make their own decisions, they think of improvement methods on their own and they implement their ideas on their own. 
Every day is a challenge for the teachers. Every class is unique. Students differ in their individual needs, learning styles, goals and personalities and the lone crusader, the teacher has to face it all alone and face it by showing equal preference for all students.

Teachers need to be recognized for the immense services they perform for the greater good of the community. They need to be nourished in a healthy, caring and challenging environment where they can fully utilize their hidden potential.The leadership in schools matters a lot for creating and nurturing an open and healthy environment where students and teachers can flourish.

\section{Servant Leadership and Teaching}

We are living in an environment that is full of ego and power struggles. Servant leaders, an oxymoron seems to be a concept that is fast catching on in all fields. The basic query remains: How can a servant be a leader? How can a leader be a servant? The term 'servant' is heavily pregnant with the implication that the individual is always under the reign of somebody else. A new approach to leadership was introduced in 1977 by Robert Greenleaf. Servant leaders according to Greenleaf are people who innately are motivated by a sense of service and putting other people first .Greenleaf (p.27) has stated, "The great leader is seen as a servant first, and this simple fact is the key to his greatness. A servant leader is a servant first. It begins with a natural feeling that one wants to serve, to serve first" Leading or occupying a pivotal position of leadership is never in the mind of the servant leader.

We can view the old leadership paradigm in the form of top-down pyramid. The order of occupancy in this pyramid top-down is as follows: CEO, President. Middle Managers, Supervisors and employees. Servant leadership is a complete reverse of this structure and places employees at the top. Johnson(2001) suggests that servant leadership is advantageous because of its simplicity, altruism and self awareness. The usual complexities in the organization process become evident when personal goals and desires of leaders are at crossroads with those of their followers. When the CEO occupies the lowest position of the pyramid, it becomes a very humbling experience wherein they understand reality and are grateful in all situations. Laub (1999) defines servant leadership as, “An understanding and practice of leadership that places the good of those led over the self interest of the leader. Servant leadership promotes the valuing and development of people, the building of community, the practice of authenticity, the providing of leadership for the good of those led and the sharing of power and status for the common good of each individual, the total organization and those served by the organization." Spears(2002) suggested that servant leadership could be characterised by the following: active listening, empathy, healing, awareness, persuasion, conceptualization, foresight, stewardship, commitment to growth, and community building.Jack Kahl(2004),former Chief Executive officer of Walmart hs said that servant leadership is the means and the end of leadership. The biggest challenge for any leadership is letting go, moving on and planning for one's obsolescence (Andy Hargreaves and Fink, 2003).Servant leaders enable the growth of others as leaders and they themselves remain at the background. This the leader does, at the cost of his own interests or desires being threatened or at his own expense. The idea here is not of subservience on the part of the leader 
or the leader being available at all times but, getting into the servant's mode while making decisions or taking action.

Teaching is a vocation, a calling and at its heart a service.It is a selfless service that teachers provide to children, parents ,society ,community ,nation and the world. There is no big incentive for people to become teachers other than an innate desire to serve.No teacher has ever got rich or famous or powerful but there is always a simple teacher behind every big and famous individual. Teaching is also not a career that everyone chooses to follow and if at all one does, it may probably because of the impact made by another teacher together with an inner calling to make a difference in other people's lives. Day et al.,,(2006) suggested that good teaching is, a very emotional experience and a humane act of connecting with students and enriching their lives with the vigour of curiosity, challenge, joy and learning and is not just concerned with knowing one's subject, being efficient, having the correct competences or having the right techniques. Teaching involves love and faith :Love for working with kids and young people on a daily basis trying to make an impact on their vulnerable minds and making them imagine what they would become if they worked for it and the infallible faith that their efforts will never be wasted and that if given the proper foundation at schools the young impressionable minds will fly high in life. The teacher has to be emotionally involved with her students because students would approach teachers not only for academic queries but also with personal problems.

Possibly there is no other profession like teaching because the only feedback the teacher can get for improving herself is the students and also a teacher cannot share her experiences with all. A teacher prides herself on improvement every single day so that each and every student gets better each day. Thus teaching is a phenomenon aimed at holistically trying to improve the pupils dealt with day after day, year after year.

Teachers in their profession contribute to strengthening the sense of belonging and shared responsibility, develop aspects of resilient qualities and thrive and flourish socially and professionally. Traditionally teachers have had very little contribution in workplace issues like choice of curriculum, kinds of tests to evaluate pupils, scheduling of classes and allocation of instructional resources. Teachers have had very little control or autonomy over their profession as a whole. This can affect productivity and commitment to the workplace and ultimately the teacher's ability and interest to teach as they fail to get the respect and the relative autonomy any professional truly expects. Katyal and Evers,( 2004) suggest that despite all this researches carried out on effectiveness of programs aimed at development of leadership abilities field of teacher education are very few

The servant leadership style of leadership has been referred to as an "Open style" of leadership by Wong(1997).This open style requires a lot of humility and integrity since the leader has to give way for anybody who has demonstrated superior ability and there is no title called "leader". There would be probably very few teachers who would not pride themselves in the growth and development of their students.Every time a famous personality appears on public media, am sure there must be a proud teacher wiping tears of joy ,going back in time when she taught him as a student. The major advantage of this open Servant leadership style is that there is no permanent leadership position and this will give rise to a number of leaders who will rise to the top, keeping interests of those served, in mind. 


\section{Conclusion}

Leadership brings to our minds a focus on change management, teamwork, collaboration and many other issues. How many leaders consider service to others as a priority more than their own growth and development. Principles of servant leadership primarily help leaders with a framework of making decisions keeping in mind the various aspects of service and orientation towards the community. Implementation of servant leadership principles will possibly ensure more sensitivity and compassion towards colleagues and students thereby enabling an open and healthy working environment in schools.

\section{References}

Day, C., Stobart, G., Sammons, P., Kington, A., Gu, Q., Smees, R., et al. (2006). Variations in teachers' work, lives and their effects on pupils:VITAE Report (DfES Research Rep. No. 743). London: Department for Education and Skills.

Greenleaf, R. K. (1977). Servant leadership: A journey into the nature of legitimate power and greatness. Mahwah, NJ: Paulist Press.

Hargreaves, A., Moore, S., Fink, D., Brayman, C., and White, R. (2003) Succeeding Leaders? - A study of principal rotation and succession, Report to the Ontario Principals' Council, Toronto, Ontario Principals' Council.

Johnson,C.,(2001).Meeting the ethical challenges of leadership.Thousand Oaks,CA: Sage

Katyal, K. R., \& Evers, C. (2004). Teacher leadership and autonomous student learning: Adjusting to the new realities. International Journal of Educational Research, 367-382.

Laub, J. A. 1999. Assessing the servant organization; Development of the Organizational Leadership Assessment (OLA) model. Dissertation Abstracts International, 60 (02).

Spears, L. C. (2002). Focus on leadership: Servant leadership for the 21st century. New York: Wiley. 